\title{
Mulheres musicistas e suas narrativas sobre o trabalho: um retrato do trabalho no Rio de Janeiro na virada do século XX ao XXI
}

\author{
Female musicians and their narratives about work: a portrait of work in Rio \\ de Janeiro in the shift to the 21st century
}

\section{Luciana Requião}

Doutora em Educação (2008) pela Universidade Federal Fluminense, onde também desenvolveu pesquisa de pós-doutorado (2009), Mestre em Música (2002) e Graduada no curso de Licenciatura em Educação Artística (1999) pela Universidade Federal do Estado do Rio de Janeiro. É professora associada da Universidade Federal Fluminense, lotada no Instituto de Educação de Angra dos Reis, e membro permanente do Programa de Pós Graduação em Música da UNIRIO (PPGM) e do Programa de Mestrado Profissional em Ensino das Práticas Musicais da UNIRIO (PROEMUS).

\section{RESUMO}

0 presente artigo busca discutir questões prementes ao mundo do trabalho no campo da música a partir das narrativas de dezenove mulheres musicistas. São mulheres que vivenciaram uma intensa transformação no mundo do trabalho na transição do século XX ao XXI, transformação esta que, não obstante seu impacto em qualquer trabalhador ou trabalhadora, apresenta particularidades relativas ao gênero. A ideia principal é identificar a forma como tais transformações afetaram a vida laboral, tendo o Rio de Janeiro como o locus central de atuação dessas trabalhadoras. Não pretendemos generalizar, mas buscar, por meio de recorrências nas falas dessas mulheres, subsídios para a compreensão de suas trajetórias, o que nos leva a perceber marcas da desigualdade de gênero.

PALAVRAS-CHAVE: Traballho; música; gênero; Rio de Janeiro.

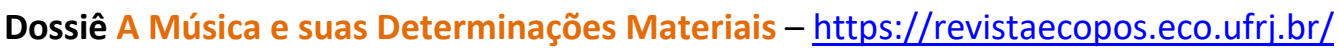

ISSN 2175-8689-v. 23, n. 1, 2020

DOI: 10.29146/eco-pos.v23i1.27436 


\section{ABSTRACT}

This article seeks to discuss urgent issues in the world of work in the field of music based on the narratives of nineteen female musicians. They are women who experienced an intense transformation in their jobs in the transition to the 21st century and who, despite the impact that these changes have on any male or female worker, show particularities due to their gender condition. The main idea is to identify how these changes have affected their job, with Rio de Janeiro as their central workplace. Differently from generalizing, we intend to find in the recurrences of the utterances of these women elements that help understand their paths, which leads us to perceive signs of gender inequality.

KEYWORDS: Work; music; gender; Rio de Janeiro.

\section{RESUMEN}

El presente artículo busca discutir cuestiones apremiantes al mundo laboral en el campo de la música a partir de las narrativas de diecinueve mujeres músicas. Son mujeres que vivieron una intensa transformación en el mundo laboral en la transición del siglo XX al XXI y que, aunque el impacto de esos cambios afecte a cualquier trabajador o trabajadora, presenta particularidades por su condición de género. La idea principal es identificar la forma como tales transformaciones afectaron la vida laboral, siendo Rio de Janeiro el locus central de actuación de esas trabajadoras. No pretendemos generalizar, sino buscar, a través de recurrencias en el habla de esas mujeres, subsidios para la comprensión de sus trayectorias, lo que nos lleva a percibir las marcas de la desigualdad de género.

PALABRAS CLAVE: Trabajo; música; género; Rio de Janeiro.

En la historia de cada artista mujer se encuentra una carrera marcada por la desigualdad de género.

Mercedes Liska, etnomusicóloga

Assim como em qualquer setor produtivo capitalista, o trabalho no campo da música vem sofrendo transformações de forma cada vez mais acirrada. Tais transformações referem-se às formas de produzir, distribuir, consumir e ainda nas relações estabelecidas entre músicos e seus contratantes. ${ }^{1}$ Tratando aqui do trabalho no campo da música popular urbana, aquela veiculada por meio de aparelhos midiáticos e

\footnotetext{
${ }^{1}$ Usamos o termo "músico" ou "musicista" para qualquer sexo ou identidade de gênero, pois é assim que, de forma geral, os/as próprios/as se auto referenciam.
}

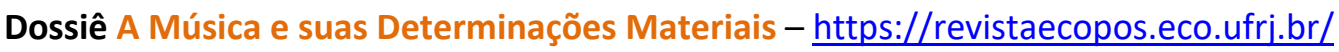

ISSN 2175-8689-v. 23, n. 1, 2020

DOI: 10.29146/eco-pos.v23i1.27436 
em sua manifestação "ao vivo" em casas de shows, bares, restaurantes, teatros e afins, a virada do século XX ao XXI testemunhou a necessidade daquele ou daquela que teve sua subsistência garantida por meio de atividades musicais "reinventar-se". Em última análise, relações de trabalho baseadas em contratos e outros mecanismos que formalizavam a relação laboral foram extinguindo-se, e essa relação foi, muitas vezes, invertida, passando o músico de contratado/a a contratante (REQUIÃO, 2010). Na atualidade, o empreendedorismo é apontado como "solução" à falta de espaços de trabalho e tido como uma forma jurídica "legal" de se contratar pessoas físicas, que necessitariam sofrer um processo de "pejotização" a partir de sua adesão ao Micro Empreendedorismo Individual - MEI (REQUIÃO, 2017).

Diante deste cenário, o presente artigo busca discutir questões prementes ao mundo do trabalho no campo da música a partir das narrativas de dezenove mulheres musicistas. São mulheres que vivenciaram uma intensa transformação no mundo do trabalho na transição do século XX ao XXI e que, não obstante o impacto dessas mudanças afetar qualquer trabalhador ou trabalhadora, apresentam particularidades por sua condição de gênero. A ideia principal é identificar a forma como tais transformações afetaram sua vida laboral, tendo o Rio de Janeiro como o locus central de atuação dessas trabalhadoras.

Em seu texto sobre mulheres musicistas uruguaias, Sheila Bonino observa que

El rol de la mujer en la música há sido un tema historicamente ignorado, cuya principal consecuencia es la falta de conocimiento de aquellas que enfrentaron a la sociedad de su época para desarrollar su talento musical y también su rol en ofícios conexos a la música. La mujer se há desempeñado en la música com grandes dificultades, há tenido que romper importantes brechas marcadas por las diferencias de género prevalecientes desde la antigüedad, pero que lentamente se han podido cambiar (BONINO, 2018, p.18).

No Brasil, Laila Rosa e Isabel Nogueira indicam que

o debate sobre gênero e feminismo em música no Brasil é emergente, tendo rendido frutos de grande importância. Contudo, reconhecemos também que o mesmo ainda é incipiente na configuração de projetos e políticas públicas no que tange a materialidade do musical e dos seus sujeitos e sujeitas (ROSA e NOGUERA, 2015, p.28).

Dossiê A Música e suas Determinações Materiais - https://revistaecopos.eco.ufri.br/

ISSN 2175-8689-v. 23, n. 1, 2020

DOI: 10.29146/eco-pos.v23i1.27436 
No campo da música de concerto, em particular no âmbito das orquestras sinfônicas, temos alguns estudos como os de Liliana Segnini. A autora relata que

As relações sociais consubstanciais de classe, gênero e raça/cor da pele informam diferenças observadas nas pesquisas quando se considera o lugar que ocupam e as trajetórias de homens e mulheres nas formas de vivenciar o campo artístico, seja no trabalho com vínculos duradouros e formais (orquestras/corpos estáveis e docência), seja no trabalho intermitente (trabalho artístico de curta duração, financiado por meio de projetos, editais, cachês e outras formas). Os dados estatísticos selecionados evidenciam que o campo da música é, de forma predominante, um espaço constituído por homens brancos (48\% do total). As relações sociais de classe, observadas por meio de entrevistas que corroboram os dados, acrescentam a importância da origem socioeconômica na formação profissional; em especial, dos intérpretes solistas, entre os quais se observa também a predominância de homens brancos (SEGNINI, 2014, p.75-76).

Já para a música popular, pela informalidade habitual em suas relações de trabalho (REQUIÃO, 2016), a mensuração fica mais difícil do ponto de vista das estatísticas oficiais - de indicadores culturais como os produzidos pela FIRJAN ou pelo IBGE; porém, é de fácil observação um quantitativo extremamente desigual entre homens e mulheres instrumentistas participantes de conjuntos, bandas e outros tipos de organização musical. Para termos uma ideia, o cadastro do Sindicato dos Músicos do Estado do Rio de Janeiro, consultado dia oito de janeiro de 2020, mostra o número de 8.146 músicos do sexo masculino e 1.805 do sexo feminino, ou seja, uma extrema desproporção, como se observa no gráfico abaixo.

\section{Proporção de Gênero}

feminino masculino

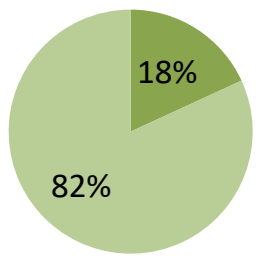

Gráfico 1: proporção entre músicos do sexo feminino e masculino cadastrados no Sindicato dos Músicos do Estado do Rio de Janeiro (elaboração própria). 
Na contramão dessa tendência, presenciamos hoje um movimento feminino na música que busca abrir espaços de ação e reflexão. De acordo com Zerbinatti, Nogueira e Pedro, "música e gênero" no Brasil é percebido como "um campo em emergência, heterogêneo, híbrido, múltiplo, construído coletivamente, como em uma 'onda' de publicações e práticas, que vem emergindo e sendo gradativa e socialmente construído no macro campo do conhecimento da música" (2018, p.2). Segundo as autoras

Estamos observando o surgimento de uma ampla e variada gama de pesquisas, autoras/es e ações precursoras, iniciadoras e continuadoras do campo, que chegam, historicamente, logo depois das primeiras pesquisas e iniciativas nessas temáticas - que, no Brasil, tiveram foco significativo em mulheres compositoras, mas não só. Ambos os momentuns ainda estão em curso, se entrecruzam, estão em diálogo, interdependência, inter-relação, se influenciam, e acontecem de forma não-linear, mas ou em simultaneidades, ou em continuidades e descontinuidades (ZERBINATTI, NOGUEIRA e PEDRO, 2018, p.6).

O debate atual vem "problematizando as ausências da produção musical das mulheres dos espaços musicais e acadêmicos", como é o caso do trabalho de Laila Rosa e Isabel Nogueira (2015, p.25), e discutindo as possibilidades da música popular, por meio de uma estética feminina/feminista, propor uma alternativa à cultura do patriarcado, como encontramos no recente texto de Marcela Velon (2019). Sem pretender identificar pioneirismos, mas reconhecendo a importância do processo histórico vivido por mulheres na luta por sua sobrevivência em um campo extremamente masculino como o da música, buscamos com o presente artigo discutir as transformações nas relações e nos processos de trabalho no campo da música - onde as questões de gênero se evidenciam - a partir da narrativa de dezenove mulheres musicistas, todas atuantes no estado do Rio de Janeiro e com uma trajetória de ao menos 30 anos de vida laboral. Apesar de algumas transitarem pela música de concerto, a atuação dessas mulheres se deu em ambientes como estúdios de gravação, casas de shows, bares e teatros, atuando como instrumentistas e/ou cantoras no âmbito da música popular.

Tais narrativas podem ser encontradas na íntegra no e-book Trabalho, música e gênero: depoimentos de mulheres musicistas acerca de sua vida laboral. Um retrato do trabalho no Rio de Janeiro dos anos 1980 ao início do século XXI (REQUIÃO, 2019). 0 livro publicado apresenta a transcrição das entrevistas, precedida por um prefácio e uma

Dossiê A Música e suas Determinações Materiais - https://revistaecopos.eco.ufri.br/

ISSN 2175-8689-v. 23, n. 1, 2020

DOI: 10.29146/eco-pos.v23i1.27436 
introdução. A intenção foi a de analisar o material coletado posteriormente, em artigos como o apresentado agora. Para a realização do livro, conforme mencionado, o recorte para a seleção das entrevistadas se deu considerando mulheres musicistas com ao menos 30 anos de atuação profissional e que estivessem ainda em atividade. É válido mencionar que uma primeira barreira foi encontrar essas mulheres. Foi difícil sair do circuito da zona sul e centro da cidade do Rio de Janeiro, apesar de contatos realizados por meio do cadastro do Sindicato dos Músicos que abrange todo o estado do Rio de Janeiro, e também de meios de circulação de músicos onde se poderia encontrar ou ter indicações de musicistas com esse perfil. Dessa forma, o recorte manteve-se mais no tempo e no espaço geográfico de atuação do que em outros aspectos que seriam também muito importantes de serem considerados, como questões de classe social e de raça, por exemplo. De todo modo, podemos observar no conjunto das narrativas singularidades caracterizadas pela origem social e/ou pela raça/cor da pele, que mostram desigualdades de oportunidades na trajetória de cada uma das musicistas.

Aqui, apresentamos uma análise das entrevistas a partir de temas e categorias recorrentes, agrupadas da seguinte forma: (1) processos de profissionalização, formação no trabalho e referências musicais femininas; (2) flexibilidade, sazonalidade e remuneração; (3) maternidade, o trabalho na noite e questões de gênero; (4) a mulher depois dos "enta", saúde e aposentadoria; (5) mercado de trabalho, modos de consumo da música e leis de incentivo; (6) perfil profissional de ontem e de hoje. ${ }^{2}$ Não pretendemos generalizar, mas buscar por meio de recorrências nas falas dessas mulheres subsídios para a compreensão de suas trajetórias, o que pode nos levar a perceber marcas da desigualdade de gênero. É o que apresentamos de forma sintética a seguir.

\footnotetext{
2 As citações aqui transcritas passaram por um processo de textualização, com a intenção de tornar a leitura mais fluente, e de compilação. Por isso, todas as citações deste livro virão apenas com referência ao nome da musicista autora da narrativa citada. Como a ideia foi a de apreender questões recorrentes, não houve a preocupação em apresentar citações das 19 musicistas entrevistadas, mas aquelas que de forma mais objetiva apresentavam algum ponto em comum à maioria das narrativas transcritas.
}

Dossiê A Música e suas Determinações Materiais - https://revistaecopos.eco.ufrj.br/

ISSN 2175-8689-v. 23, n. 1, 2020

DOI: 10.29146/eco-pos.v23i1.27436 
Comecei a fazer alguns trabalhos profissionais quando tinha uns 20 anos. É claro que, na época, eu não me sustentava com o trabalho de música, mas foi quando comecei a atuar... fazer uma gig aqui, outra ali...

Sueli Faria

O processo de profissionalização de mulheres que buscaram sua subsistência no campo da música no estado do Rio de Janeiro nos idos dos anos 1980 começa por volta dos vinte anos de idade. Naquele momento, a indústria fonográfica já havia se consolidado no Brasil, e iniciava um processo de profundas transformações em seu modo de produção. De um modelo de produção fordista, em que verticalmente se cumpria todas as etapas de produção, a indústria passava paulatinamente a terceirizar grande parte dessas etapas e a diversificar seus produtos.

Com o desmantelamento da grande indústria (major) como a detentora de todas as etapas do processo produtivo e a aceleração dos processos de terceirização e subcontratação, pode-se observar o crescimento de empresas fonográficas de pequeno porte (indies) que passam a ser as reais produtoras do produto fonográfico (REQUIÃO, 2010, p.110).

De acordo com Vicente (2002), a cena musical da década de 1980 presenciou o investimento das grandes gravadoras em segmentos populares que têm como público alvo o mercado jovem urbano, destacando a emergência do popular-romântico, do sertanejo, da música infantil e do rock brasileiro. Do ponto de vista artístico, a atividade musical naquele momento parecia bastante estimulante. ${ }^{3} \mathrm{Na}$ faixa dos 20 anos de idade,

\footnotetext{
${ }^{3}$ Compositores e empresários ganham destaque nesse processo. "Esse é o caso, por exemplo, da dupla de compositores Michael Sullivan e Paulo Massadas, que em 1983 têm seu primeiro sucesso comercial com a música 'Me dê motivo', lançada no disco $O$ descobridor dos sete mares do cantor Tim Maia, pela Polygram" (REQUIÃO, 2010, p.120). Vicente informa que empresários "tendem a ganhar maior relevância não só pelos seus investimentos na promoção de seus contratados, mas também pela estrutura técnica e
}

Dossiê A Música e suas Determinações Materiais - https://revistaecopos.eco.ufrj.br/

ISSN 2175-8689 - v. 23, n. 1, 2020

DOI: 10.29146/eco-pos.v23i1.27436 
as cantoras, principalmente, tinham como referência crooners e cantoras de sucesso com carreiras sólidas, e era provavelmente isso o que buscavam.

Na minha cabeça, vida de cantora era Nana Caymmi. Eu morava ao lado do Chico's Bar, então via a Leny, Biba Thompson, via a Nana e, para mim, carreira de cantora era beira de piano, copo de whisky, cantando fossa, em boate. Era esse o meu imaginário. Era uma realidade nos anos 80 , no Rio havia vários piano bar. E eu mirei muito nisso (ANDREA DUTRA).

Com grandes e pequenas gravadoras instaladas no Rio de Janeiro e uma produção baseada na segmentação e diversificação de produtos, havia, certamente, uma grande demanda de trabalho para instrumentistas, arranjadorxs e cantorxs para o coro, frequente nas gravações da época.

Comecei a cantar profissionalmente muito nova. Estava cantando na noite, fazendo shows e trabalhando também em estúdio de gravação intensamente. Trabalhei para todas as gravadoras que existiam na época. Na verdade, vivi 22 anos como cantora e vocalista, e muito nova eu já era independente financeiramente. Pagava aluguel, tinha carro, e morava na minha própria casa, sozinha, tinha a minha vida, me bancava com o rendimento de cantora. Trabalhava na noite e em estúdio, de dia (LUNA MESSINA).

Possivelmente tal diversificação da indústria propiciou a abertura de espaços para apresentações ao vivo, como os teatros, bares e casas de shows. A noite carioca fervia!

A gente fazia tanto shows quanto barzinhos. Olha... neste começo de carreira, nos anos 1980, de 1983 a 1988, o Rio tinha muito espaço para show. Para você ter uma ideia, esses cinco anos foi a época em que eu mais fiz show no Rio de Janeiro. A gente ficou na Sala Funarte por duas semanas, de sexta a domingo, com direito a ensaio geral na quarta. Era assim, a temporada era de duas semanas (CLARA SANDRONI).

As oportunidades de trabalho, fartas na época se comparadas ao quadro atual, permitiam que a formação para o trabalho viesse da experiência adquirida no trânsito

profissional que passa a fornecer a seus shows, incluindo modernos sistemas de som e iluminação" (VICENTE, 2002, p.102).

Dossiê A Música e suas Determinações Materiais - https://revistaecopos.eco.ufrj.br/

ISSN 2175-8689-v. 23, n. 1, 2020

DOI: 10.29146/eco-pos.v23i1.27436 
por diversas atividades laborais, em especial a partir do contato com músicos mais experientes, de outra geração.

Eu aprendi muito a profissão na lida, na experiência prática de tocar. Tive o privilégio de tocar com grandes músicos de uma geração que já estava quase saindo do mercado. Grandes músicos, como o Maestro Cipó, o Juarez Araújo... Nossa! Tantos nomes de instrumentistas, de sopro especialmente, seriam muitos para citar. É aquela geração que teve uma atuação importante nos anos 1960, que foi um tempo áureo para a música instrumental brasileira (SUELI FARIA).

Para essa geração havia ainda a referência da chamada "música independente", aquela que buscava alternativas para a viabilização de sua subsistência na música, como a autoprodução. 0 barateamento das tecnologias de gravação e a disponibilidade de espaços para divulgação do trabalho musical instigava a nova geração a seguir esse caminho.4 "A gente deu continuidade ao movimento musical independente, ocupando os espaços com música brasileira. Seguiu os passos do Antonio Adolfo, da Joyce, do Boca Livre, do Céu da Boca, junto com outros grupos. Nessa época havia diversos grupos independentes" (CLARA SANDRONI).

Diferentemente das cantoras, as referências musicais de "grandes instrumentistas" eram exclusivamente masculinas, salvo uma ou outra rara exceção. "Os meninos, desde muito cedo, ficam brincando: 'Ah, eu sou o guitarrista, eu sou o baixista, eu sou o John Lennon, eu sou o Paul'. E isso, até hoje uma referência..." (DELIA FISCHER). A falta de referência de "grandes" mulheres instrumentistas parece afetar ao menos dois aspectos da vida laboral de mulheres musicistas. 0 primeiro deles refere-se à demanda.

Quando a pessoa vai pensar em fazer um trabalho, logo surgem muito mais homens na mente. Nós temos um monte de bandas grandes só de homens, não porque não haja mulheres com capacidade de estar ali tocando. Experiências que tenham mulheres dirigindo os trabalhos são experiências raras, são fenômenos atípicos (SUELI FARIA).

\footnotetext{
4 "Foi nesse período, quando a grande indústria fonográfica brasileira mantinha seu foco direcionado para segmentos específicos e pelo melhor acesso de músicos aos meios de produção tecnológicos, que a produção chamada de "independente" começa, de certa forma, a ganhar espaço" (REQUIÃo, 2010, p.122)
}

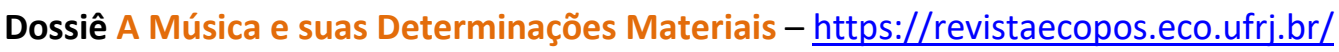

ISSN 2175-8689-v. 23, n. 1, 2020

DOI: 10.29146/eco-pos.v23i1.27436 
A segunda, como consequência também dessa primeira, mas não só, refere-se ao próprio desempenho da mulher instrumentista, já que, como vimos, a experiência no trabalho é fator determinante nos processos formativos. "O mercado não oportuniza o despontar dessas grandes musicistas. Você ver uma mulher tocando pra caramba é difícil" (KATHILA VALVERDE).

É muito mais difícil para uma mulher chegar à frente de um grupo e improvisar, por exemplo, assumir o papel de protagonista, naquele momento onde todas as atenções se voltam pra você, do que pra um homem. A gente tem muito mais trabalho para conseguir chegar nesse ponto. E eu acho que isso fica muito introjetado na mulher. Não é falta de capacidade, é uma dificuldade a mais pra conseguir se expor dessa forma e assumir esse papel de protagonista na situação musical (SUELI FARIA).

Outro ponto importante a ser destacado é que, se a condição feminina traz certa unidade na experiência laboral dessas mulheres por terem atuado em um mesmo território (o Rio de Janeiro) e em uma mesma época, a condição social apresenta particularidades.

0 músico de subúrbio quando chega em um contexto Zona Sul é sempre um choque. Para ambas as partes, mas principalmente para a galera Zona Sul, que prefere que o cara more mais perto. Querem um cara que não atrase nunca, que tenha aquelas facilidades que uma pessoa que vem de uma realidade de subúrbio não vai ter (MONICA AVILA).

As dificuldades de adquirir um instrumento e a possibilidade de ingresso na universidade ou em bandas militares por meio de concurso público são também relatadas.

Não conseguia comprar um instrumento, e os anos iam passando, passando. E daí consegui comprar a flauta, uma flauta muito ruim, mas consegui uma flauta transversa. Já estava terminando os estudos e cismei que queria fazer música na universidade, mas nenhuma delas me aceitou. Eles não me aceitavam de jeito nenhum. Eu estudava, estudava, estudava... nunca passava [na habilidade específica]... tentei várias vezes. Cheguei a comprar outras flautas, a melhorar, a estar me sentindo realmente bem preparada (MONICA AVILA).

Morando na comunidade sem ter muito recurso, a gente quer o quê? Trabalhar! Daí você tenta entrar em uma banda militar, como eu tentei. Para prova da guarda,

Dossiê A Música e suas Determinações Materiais - https://revistaecopos.eco.ufri.br/

ISSN 2175-8689-v. 23, n. 1, 2020

DOI: 10.29146/eco-pos.v23i1.27436 
prova para o bombeiro... Sem condição, porque tem muito "peixe". A gente sabe disso. Muitos "peixes" de quem tem contato lá dentro. Passei em quinto lugar em uma. Passei em sexto lugar na outra. Da outra vez, cheguei até em terceiro, mas era uma vaga só. No bombeiro, foi a pior. Eu estudei para caramba! Muita coisa! Estudei uma peça de confronto, cheguei lá e tirei zero! Como é que você dá zero para uma pessoa que já toca? Que estuda uma peça de confronto?! (KATIA PRETA)

\section{Flexibilidade, sazonalidade e remuneração}

Vida de músico é sempre assim: ou você faz dez coisas ao mesmo tempo ou pode ficar dois meses sem fazer nada. Acabou um trabalho e não pintou outro, e, de repente, quando pinta o primeiro, pintam três seguidos. A vida da gente é isso... Foi sempre assim. Celia Vaz

Um marco na busca de trabalhadores e trabalhadoras do campo da música na sua organização como classe profissional foi a criação do Centro Musical do Rio de Janeiro (CMRJ), em quatro de maio de 1907. 0 CMRJ passou a estatuto de sindicato no ano de 1941, e hoje vem a ser o Sindicato dos Músicos do Estado do Rio de Janeiro - SindMusi (ESTEVES, 1996). ${ }^{5} \mathrm{Na}$ ocasião, músicos puderam se beneficiar de direitos trabalhistas propiciados pelo Estado Novo (1937-1945), como aumentos salariais e o direito a férias (MAESTRI, 2019, p.115), e havia oportunidades para a atuação em postos de trabalho estáveis. Empresas radiofônicas como a Rádio Mayrink Veiga, por exemplo, em atividade entre os anos 1926 e 1965 no Rio de Janeiro, pôde empregar músicos por longos períodos (alguns por décadas) com aumentos salariais regulares, férias e proventos mensais. No ano de 1960, a música passa a ser uma profissão regulamentada pela Lei 3.857 (BRASIL, 1960).

Não obstante haver regras para a contratação de músicos como assalariados ou em trabalhos eventuais, como é o caso da Nota Contratual, ${ }^{6}$ as relações de trabalho passam, em grande parte, pela informalidade.

\footnotetext{
50 SindMusi está localizado na Rua Álvaro Alvim 24, sala 405, Cinelândia, Rio de Janeiro.

${ }^{6}$ A nota contratual foi aprovada pela Portaria no 3.406, de 25 de outubro de 1978, como instrumento de contrato de prestação de serviços eventuais para artistas e técnicos em espetáculos (BRASIL, 1978).

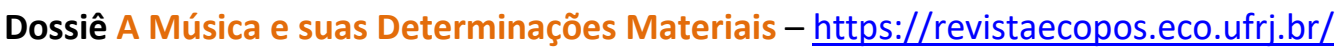

ISSN 2175-8689-v. 23, n. 1, 2020

DOI: 10.29146/eco-pos.v23i1.27436
} 
0 meu primeiro emprego foi no Number One, uma boate em Ipanema. Nos três primeiros meses fiquei na experiência, sem nenhuma formalização. E nos outros meses pediram a carteira de trabalho, que ficou com eles até o final, mas nunca assinaram. As gravações eram as gravadoras estrangeiras, que tinham todo um esquema. Aí sim tinha um recibo (LUNA MESSINA).

As relações pessoais são apontadas como uma forma de constrangimento à exigência de garantias e direitos trabalhistas.

Uma coisa que sempre me chamou a atenção é que muitas pessoas que organizavam bandas e contratavam, chamavam os músicos para tocar e não diziam quanto era o cachê. Isso era uma prática muito comum. Era sem contrato, sem nenhuma garantia, pago diretamente, e algumas vezes também você não recebia, acontecia isso também... ou demorava bastante para receber porque, às vezes, a pessoa que organizou o trabalho também não recebia. Então, por consideração àquela pessoa (porque geralmente era um músico amigo, conhecido, que já tinha te chamado pra outras coisas) a gente considerava que estava no risco junto com ele também. Nesse aspecto das garantias, dos direitos do trabalho, sempre foi uma profissão pouco profissional, digamos assim, meio amadora nesse sentido, você não tinha garantia nenhuma (SUELI FARIA).

0 mercado fonográfico parece ser o que garantiria uma remuneração mais volumosa, em função da grande demanda, de forma a permitir uma estabilidade profissional. “0 mercado de gravação era bastante estimulante, era um dinheiro rápido e justo, que fortalecia o status de músico-instrumentista profissional. Tocou, recebeu pela tabela, assinou o recibo e garantiu seus direitos conexos, pronto!" (ANDREA ERNEST DIAS). ${ }^{7}$ A televisão e algumas casas de shows também possibilitavam contratos mais formalizados. "Trabalhei alguns anos na Globo, fixa, de carteira assinada. Trabalhei no Canecão, com carteira assinada também" (HELENA BUZACK). Porém, de forma geral, a informalidade parece ser a tônica: "Setenta por cento do dinheiro que eu recebi na minha vida de cantora, nesses anos todos, foi dinheiro informal, de mão para mão, sem documento, sem recibo, sem nada. Aquele dinheiro totalmente não oficial" (ANDREA DUTRA). As aulas de música foram ainda uma possibilidade para se manter nesse

\footnotetext{
${ }^{7}$ A tabela a que se refere a musicista é a Tabela de Cachês Mínimos para Trabalhos Eventuais criada pelo SindMusi, como referência de valores para pagamento de cachês. Disponível em: <www.sindmusi.org.br.> Acesso em 10 jan. 2020.
}

Dossiê A Música e suas Determinações Materiais - https://revistaecopos.eco.ufri.br/ ISSN 2175-8689-v. 23, n. 1, 2020

DOI: 10.29146/eco-pos.v23i1.27436 
mercado: "os músicos estão sempre dando aula. Eles tocam e dão aula e aí conseguem financiar a própria vida" (CLARA SANDRONI).

As narrativas aqui citadas mostram a necessidade de um perfil flexível, que permita às trabalhadoras transitar por diversos ambientes laborais.

Trabalhei em peças de teatro, fiz muita gravação e toquei no Canecão. A gente saía da Globo à noite, tarde, muitas vezes com o sol na cara, para ir pra Sinfônica, direto. Eu trabalhei em vários lugares para ter uma vida melhor. Então, era sempre assim: as oportunidades apareciam embora não pagassem tão bem. Mas, no cômputo geral, dava para viver (HELENA BUZACK).

A sazonalidade associada à informalidade pode justificar a necessidade desse perfil flexível. "Em todos os anos, nos meses de janeiro, fevereiro e março tinha muito poucos shows e nenhum suporte para você em relação a isso" (DEBORAH LEVY).

E tem aquelas épocas que acumula trabalho pra caramba, que você tem que dar conta de um excesso de trabalho, e tem aquelas épocas que não tem trabalho. Na música tem muito essa sazonalidade. Por exemplo, o tempo de dezembro a março é um tempo muito ruim, com exceção dos trabalhos de carnaval (SUELI FARIA).

Tal fato acarreta sentimentos negativos em relação ao trabalho.

É uma constante. Na minha vida tem sido. E isso é uma coisa que me incomoda um pouco porque, por exemplo, o fato de não ter segurança, não ter um salário, não ter uma rotina, isso não seria tão sério se, por exemplo, ao acabar um trabalho, logo em seguida já tivesse outro trabalho engatilhado; essa insegurança, acho que não existiria (LILIANE SECCO).

$\mathrm{Na}$ vida laboral das cantoras parece haver algumas particularidades. Pela necessidade, muitas vezes, de se autoproduzir, as cantoras relatam dificuldades em sobreviver nesse campo de trabalho.

O que acontece é que eu era dona do trabalho, mas não era uma banda. Tudo que eu ganhava era para pagar os caras, e eu sempre quis pagar direito (dentro do possível, dentro daquilo que eu ganhava). 0 trabalho de cantora tem que ser bancado, não é como o de músico, que alguém te chama e te paga. Não conheço nenhuma que seja diferente. Porque ninguém te chama para cantar e te paga um cachê (ANDREA DUTRA). 


\section{Maternidade, o trabalho na noite e questões de gênero}

"Toca que nem homem?" Ah, já... já ouvi essa frase várias vezes. Não há expressão mais lugar comum do que essa. Andrea Ernest Dias

O mundo do trabalho no campo da música é masculino. "Já começo daí, não tinha 'as produtoras', só tinha 'os produtores', 'o diretor', 'o artista'. 'A artista', normalmente, não tinha muita voz ativa no seu próprio trabalho" (LUNA MESSINA). Um ambiente de trabalho masculino provavelmente favoreceu padrões machistas de comportamento.

0 ambiente de trabalho é um ambiente machista, no sentido de que se reproduzem formas de relação com a mulher, mesmo que não seja diretamente com você. Comigo sempre houve um respeito, mas era generalizado as posturas machistas em relação às mulheres. A gente tinha que ouvir "pérolas", tinha que assistir a "pérolas" machistas na relação entre homens e mulheres. Mas também sempre tentei me colocar de uma forma que me respeitassem (SUELI FARIA).

Como visto, se há dificuldade da mulher assumir um papel protagonista na cena musical, em alguns gêneros musicais isso pode ser extremo. "A mulher não tem voz, não tem vez, tanto que, se você prestar atenção, o pagode não deixa nem mulher entrar, não tem cantora. Não tem nenhuma. Nem uma!" (ANDREA DUTRA). Se a aprendizagem no trabalho é fator primordial, algumas consequências são sentidas.

Primeiro, se você é mulher, já é difícil conversar com um homem, porque muitas vezes ele não considera o que você está falando - como se ele ficasse esperando chegar um homem que vá resolver o problema. Passei muitos anos sem conseguir aprender e entender a minha voz amplificada porque o técnico não colaborava com esse aprendizado (CLARA SANDRONI).

A mulher enfrenta uma imagem estereotipada que se tem a seu respeito: "a cantora tem que ser bonita, tem que estar de minissaia, tem que estar de não sei o quê. Tem um certo apelo na expectativa das próprias pessoas em relação a elas" (CRISTINA BHERING). Tal expectativa é sentida até mesmo em relação ao instrumento que toca. "Por que não toca um violino?", "Qual é o seu problema?" "Por que você tem que tocar esse instrumento tão grande?" Isso eu ouvi várias vezes! (SUELI FARIA); “Como é que

Dossiê A Música e suas Determinações Materiais - https://revistaecopos.eco.ufri.br/

ISSN 2175-8689 - v. 23, n. 1, 2020

DOI: 10.29146/eco-pos.v23i1.27436 
você vai tocar trompete? Mulher não toca trompete!” (GUTA MENEZES); “Essa mãozinha é muito delicada para tocar saxofone'. Falou assim, na frente da turma e, obviamente, a turma só tinha homem, não tinha mulher" (MONICA AVILA). "Você me imagina entrando em um ônibus, com um negócio desse tamanho [trombone], todo mundo me olhando, e eu com uma vergonha danada porque, naquela época, até a gente mesmo tinha preconceito" (KÁTIA PRETA).

O desconforto causado por situações como essas provocaram a necessidade de uma postura defensiva. "Era eu comandando seis homens instrumentistas, só eu de mulher. Se a gente começar a sorrir muito - e eu gosto de sorrir, de brincar -, mas se a gente começa a ficar muito sorridente, já pode dar margem..." (CRISTINA BHERING). Em todos os casos assédios foram relatados.

Eu sofri constrangimentos de produtor, de dono de estúdio, algumas situações foram bem constrangedoras. Mas principalmente dos produtores da gravadora. Uma vez o dono de uma gravadora, de um estúdio de gravação, sentado em frente a mim, pegou a mão assim, enfiou no bolso, pegou um monte de dólar, abriu os dólares em leque e começou a se abanar olhando pra mim fixamente, sabe? E ele era o dono, o dono daquele espaço que eu trabalhava sempre, era uma situação totalmente constrangedora, entendeu? Não tive o que fazer a não ser levantar e ir embora... E o pior, a gente não podia prejudicar os colegas, ainda tinha essa questão, se você fosse muito dura com aquele sujeito você ia prejudicar os colegas que costumavam trabalhar junto contigo (LUNA MESSINA).

O ambiente do trabalho na noite é, particularmente e por diversas razões, identificado como inóspito ou desqualificado. "Era um ambiente extremamente machista. Não tinha nenhuma mulher tocando, nada. Só tinham cantoras, que, em geral, eram mulheres mais velhas" (MONICA AVILA).

0 trabalho de músico da noite é um trabalho bastante desvalorizado. Você não é considerado um artista. Mas o fato de tocar na noite, tocar em bailes, muitas vezes no subúrbio, há uma discriminação, como se fosse um artista menor, um trabalhador menor (SUELI FARIA).

Em relação ao trabalho na noite, as musicistas relatam ainda outras dificuldades...

Não conseguia alugar um apartamento. Na primeira vez que quis alugar um apartamento foi impossível. Tive que pegar não sei quantos papéis... meu pai teve

Dossiê A Música e suas Determinações Materiais - $\underline{\text { https://revistaecopos.eco.ufri.br/ }}$

ISSN 2175-8689 - v. 23, n. 1, 2020

DOI: 10.29146/eco-pos.v23i1.27436 
que assinar não sei quantos papéis... Ele é que teve que dizer: "Não... eu tô deixando ela alugar o apartamento. Tudo bem. Ela pode alugar pra ela. Não tem problema". Tive que pegar um monte de recomendação para a pessoa poder alugar o apartamento pra mim. Já começou assim. E daí foi sempre assim, você dizer: "Sou cantora". A pessoa olha pra tua cara: "Cantora lírica?" Porque acho que cantora lírica é mais respeitada (LUNA MESSINA).

...e preconceitos.

"Não dá para ficar com uma mulher que tem a vida que você tem. Não dá para ficar com uma mulher que fica na noite, chega em casa três horas da manhã, ou está no centro das atenções o tempo inteiro. Que vida é essa em que a pessoa acorda 11 horas da manhã todo dia? Isso não é vida!" Eu já fui discriminada assim, da pessoa dizer "Sai fora! Eu não quero uma pessoa que tem esse tipo de vida" (ANDREA DUTRA).

Algumas marcas de gênero se sobressaem ao conhecermos a trajetória de mulheres musicistas. Em um mercado onde o ritmo de trabalho mostra-se extremamente intenso e inseguro - do ponto de vista da demanda e da remuneração -, além de competitivo, podemos imaginar o que a maternidade pode representar. "Por ter tido dois filhos interrompi os estudos e a carreira por tanto tempo" (HELENA BUZACK). Mesmo quando não provocava interrupções em seu percurso profissional, a maternidade significava sobretrabalho, se comparado à rotina masculina.

Porque a gente cumpria os mesmos horários, fazia tudo exatamente igual aos meus colegas homens, mas a gente tinha uma dupla jornada também. Muitas vezes tinham que levar o filho para a gravação e manter o filho quietinho, calado, sem atrapalhar a gravação. E isso só quando o produtor permitia, ou achava que aquilo não fosse atrapalhar o trabalho. Então, isso sempre foi complicado para as mulheres (LUNA MESSINA).

Como contraponto à necessidade de interromper a trajetória para cuidar dos filhos, uma alternativa foi conjugar os cuidados maternais com o trabalho.

Quando a Mariana nasceu eu parei $O$ Santo Inquérito. Eu fiz a gravidez toda (tinha carteira assinada e tudo), até o oitavo mês. No nono mês não trabalhei, porque tinha que subir uma escada. Levava a Mariana para o teatro, levava na cestinha, ao Parque Laje, me lembro, estava com ela na cestinha, fazendo espetáculo lá (IGNES PERDIGÃO).

Dossiê A Música e suas Determinações Materiais - https://revistaecopos.eco.ufri.br/

ISSN 2175-8689 - v. 23, n. 1, 2020

DOI: 10.29146/eco-pos.v23i1.27436 
Como consequência, a mulher "é multitarefa, é multiatenção, tem que estar, ao mesmo tempo, segurando várias coisas. É diferente do homem, que é preparado para exercer o seu papel profissional, digamos, mais plenamente, mais liberado de outras preocupações" (SUELI FARIA).

Viver como instrumentista é algo muito difícil, é um meio bem disputado. Agora percebo melhor que se trata de uma desigualdade de gênero, de um machismo que ainda não foi suplantado. Muitos homens com carreira de sucesso no instrumental, no jazz e no choro, por exemplo, têm uma mulher parceira que assegura essa estabilidade. Muitas trabalham para o sucesso do próprio companheiro, como empresárias e produtoras exclusivas. Então, quando uma mulher se destaca como instrumentista nesse mercado, é considerado algo fora do comum, ainda hoje. É preciso reivindicar esse espaço a que temos direito, falar sobre o assunto até que a situação se naturalize (ANDREA ERNEST DIAS).

As características do trabalho no campo da música foram identificadas como um dos fatores determinantes na não opção pela maternidade. "Eu não tinha hora: trabalhava fim de semana, ensaio de noite. No fim de semana tinha que estudar instrumento. Eu tinha certeza de que não iria caber um filho, provavelmente eu nem teria feito música." (CRISTINA BHERING); “Não tive coragem de ter filho, porque sempre achei que filho atrapalharia a minha carreira, porque eu teria que trabalhar em outra coisa pra ter essa grana fixa que a música não traz e que filho exige. Optei pela carreira" (ANDREA DUTRA).

A minha profissão nunca me deu condições de ter, dentro do que eu entendia, de poder ter uma estrutura para ter um filho, criar um filho, sem depender da ajuda de família, coisas que eu achava que tinha que dar conta. Então, da forma como me conduzi profissionalmente, nos momentos em que tinha vontade ainda de ter um filho, isso se manifestou como um impedimento. Como é que eu vou trabalhar? Como é que eu vou sustentar? Como é que eu vou ter grana para pagar alguém para ficar com a criança, na medida em que também não tenho família aqui, estou distante da minha família? Era uma coisa que teria que assumir e nunca tive, efetivamente, condições materiais, fruto do meu trabalho (como música) que me possibilitassem essa opção. Isso foi bastante determinante, não foi a única questão, mas foi bastante determinante por optar pela não maternidade (SUELI FARIA).

Outras discriminações foram ainda relatadas, em relação ao corpo...

Dossiê A Música e suas Determinações Materiais - https://revistaecopos.eco.ufri.br/

ISSN 2175-8689 - v. 23, n. 1, 2020

DOI: 10.29146/eco-pos.v23i1.27436 
Eu não sofri como mulher, mas como deficiente. Uma vez, fiquei muito danada com um colega. Alguém me falou que não iam me colocar na banda por eu ter um problema físico. Isso me machucou, me doeu muito. Sofro esse preconceito desde que nasci, tive poliomielite com 10 meses (CELIA VAZ).

...ou ao próprio fato de ser mulher.

Nunca trabalhei com cantor, nunca me chamaram para trabalhar em banda com uma cantora, por exemplo, o que poderia ser uma alternativa de trabalho. As coisas que me vieram à cabeça são: competição (porque eu sou mulher e a cantora também é mulher); e por causa de precisar ter quartos separados - eu sempre pensei que, por ser mulher, precisasse de quartos separados, e então talvez a gente fosse custar mais caro (DANIELA SPIELMANN).

\section{A mulher depois dos "enta", saúdle e aposentadoria}

Já percebi que a demanda caiu bastante para mim e vejo as pessoas mais velhas do que eu sem trabalhar. Andrea Dutra

Uma questão que pouco aparece no debate feminista na música, e por isso se faz necessário ressaltar, é a questão da idade. As narrativas aqui citadas mostram alguns aspectos relacionados à faixa etária que têm como consequência o paulatino afastamento das atividades laborais. "No Democráticos começava meia-noite e terminava às quatro da manhã, eu não tenho mais condição!" (DANIELA SPIELMANN).

O próprio envelhecimento faz com que determinadas condições do trabalho de músico da noite, por exemplo, já sejam muito cansativas. Passei a ter necessidade de melhores condições de trabalho porque, senão, seria muito perigoso, seria muito sacrificante, seria muito cansativo. Na medida em que fui precisando de melhores condições, e o mercado foi me oferecendo piores condições, a expectativa de viver de música morreu para mim (SUELI FARIA).

No final da minha vida [laboral] eu tive que diminuir... E começam as limitações, né? 0 joelho, tendinites, coluna, síndrome de carpo... Por causa da LER fui condenada à cirurgia da Síndrome do Carpo, nos dois pulsos. Eu não tenho sensibilidade na ponta dos dedos, tinha momentos em que não sabia em que corda o dedo apertava! (HELENA BUZACK)

Dossiê A Música e suas Determinações Materiais - $\underline{\text { https://revistaecopos.eco.ufri.br/ }}$

ISSN 2175-8689-v. 23, n. 1, 2020

DOI: 10.29146/eco-pos.v23i1.27436 
Além de questões relacionadas à saúde, a aparência da mulher musicista depois dos quarenta ou cinquenta anos parece ser determinante na oferta (ou não) de trabalho, o que não seria tão impactante para o homem músico.

Sempre toquei com caras muito mais velhos do que eu: o Zé Menezes, o Sivuca, o Juarez, e vi o envelhecimento desses caras... é bem pior [para a mulher]. Perde aquela coisa da "boazuda". Claro que as gigs que a gente faz são instrumentais e nem tem tanto isso, mas tem aquela coisa do cara que chama: "A Loirinha do Sax", "A Moreninha do Piano". Daí vai ser o quê? "A Coroa do Samba"? Quanto tempo mais eles vão querer colocar gente enrugada de cabelo branco num palco? (DANIELA SPIELMANN).

Há ainda uma provável disputa de mercado com mais novos que estão entrando nesse campo de trabalho. "Fora que tem a galera nova, que vai se formando. Foi o meu caso: eu tocava com a minha galera, que eram meus amigos, meus colegas, que cresceram junto comigo. A partir do momento em que você vai envelhecendo, vai ficando meio de fora" (DANIELA SPIELMANN).

A primeira coisa que na música se faz, na minha opinião, é começar a deixar de convocar os mais velhos. Porque os mais velhos estão tomando o lugar de quem está querendo entrar no mercado. Então o mais velho é olhado assim como " $A h$, esse cara ainda tá tocando, poxa, porque é que ele não para?" (LUNA MESSINA).

A preocupação com a aposentadoria, em geral, aparece tardiamente - "comecei a pagar o INSS depois de alguns anos de trabalho" (CELIA VAZ) -, o que leva à busca por alternativas, em geral encontradas na atividade docente.

Cheguei aos 50 anos e aí que comecei a me preocupar com a questão do futuro, de aposentadoria... que sempre contribuí como autônoma, mas era assim, uma coisa pelo mínimo. Aí fiz um concurso público. Eu já havia tido outras experiências anteriores como professora de música, mas foram experiências em escola, mais eventuais. Fiz um concurso e entrei na FAETEC, e foi justamente pela questão da sobrevivência, de necessidade de sobrevivência e de estabilidade, pensando inclusive em questão de aposentadoria, porque eu vi que de outra forma não seria possível, seria inviável me manter (SUELI FARIA).

Fiquei na Globo de 2000 a 2014. Só saí quando entrei para o CEFET, quando fiz o concurso público. Já tinha feito outros concursos porque sempre tive medo de ficar desempregada. Eu sempre tive muito medo de ser despedida da Globo, então nunca desfiz da minha vida de guigueira, ela se manteve. Eu gosto de dar aula

Dossiê A Música e suas Determinações Materiais - https://revistaecopos.eco.ufri.br/

ISSN 2175-8689-v. 23, n. 1, 2020

DOI: 10.29146/eco-pos.v23i1.27436 
também, não é problema dar aula, mas talvez não tivesse ido dar aulas se pudesse sobreviver como instrumentista (DANIELA SPIELMANN).

Uma fala muito impactante da saxofonista Daniela Spielmann mostra o quanto a categoria musical, em especial aqueles que vivem do próprio trabalho, não tem uma preocupação com a idade avançada, e o quanto o mercado informal os deixa à deriva.

Uma das cenas mais marcantes que vi na minha vida, que foi também o que me levou ao magistério na busca por estabilidade, foi ver o Juarez Araújo - que foi meu professor e considerado um dos maiores saxofonistas do Brasil, mas que no Brasil infelizmente esse tipo de coisa não significa nada em termos de emprego -, falecer em hospital do INSS, naqueles leitos múltiplos. Aquilo me deixou muito... Cara, o sujeito mais velho, depois de gravar com Simonal, com a Gal, milhões de coisas feitas e com a velhice horrorosa, sabe? Tenho essa coisa de medo de envelhecer, porque acho que tem uma questão de velhice também com a música. E é coisa séria, chocada (DANIELA SPIELMANN).

\section{Mercado de trabalho, modos de consumo da música e leis de incentivo}

Hoje em dia não sei como seria viver disso da forma autônoma como eu vivi.

Maria Teresa Madeira

As frequentes interrupções na carreira por conta de questões familiares e/ou da maternidade aliadas ao envelhecimento do corpo - todas as narrativas são de mulheres acima dos 45 anos de idade - em um mundo do trabalho masculino e com preconceitos de diversas ordens se somou a transformações particulares ocorridas no mundo do trabalho no Rio de Janeiro: "Não teve mais orquestra, não tem mais gravadora. Antigamente, era uma festa! Porque as gravadoras ganhavam muito dinheiro, pagavam muito bem, bancavam uma orquestra inteira para você fazer o arranjo. Depois começou a não ter mais tanto trabalho para o arranjador" (CELIA VAZ);

Em 1988 foi quando todas as gravadoras começaram a se desmontar. Todas as grandes gravadoras e também as produtoras de jingle se mudaram para São Paulo. A gente aqui no Rio ficou a ver navios. Acabou! O tipo de trabalho que eu tinha, que era fazendo backing e criando vocais para muitos artistas de renome, em várias gravadoras e também em produtoras de jingle, isso tudo minguou. Pra ter uma ideia do volume de trabalho, eu chegava ao ponto de trabalhar de nove da manhã

Dossiê A Música e suas Determinações Materiais - https://revistaecopos.eco.ufrj.br/

ISSN 2175-8689-v. 23, n. 1, 2020

DOI: 10.29146/eco-pos.v23i1.27436 
às três da madrugada. Era assim... recebendo por período de gravação seguindo a tabela do sindicato dos músicos... a gente trabalhava muito mas ganhava o suficiente para viver bem. Não consegui manter o mesmo padrão (LUNA MESSINA).

As narrativas enfatizam o quanto decaíram as oportunidades de trabalho no meio fonográfico, uma área que, ao menos na ocasião, parecia ser a espinha dorsal da cadeia produtiva da música.

0 dinheiro maior que rolava da música era industrial, era dos discos, não era entretenimento, música para bar, isso era complemento. Qual é o show que dá dinheiro a músico? Me diga, qual? Você já fez algum show que ganhasse dinheiro? Que você saísse e dissesse: "Opa! Valeu a pena, ganhei pelo menos uma semana de trabalho?" Então, isso é irreal, não existe (IGNEZ PERDIGÃO).

Mesmo se considerada como renda complementar, as apresentações ao vivo também oportunizaram para algumas musicistas a possibilidade de um trabalho estável e longevo. "A gente tinha um salário fixo por mês, carteira assinada, toda a estrutura. E lá fiquei 15 anos tocando [Rede Globo]. Também teve o Árabe da Lagoa, fiquei lá 18 anos" (GUTA MENEZES). Porém, de forma concomitante à mudança geográfica de grandes e pequenas gravadoras, a oferta de trabalho por meio de apresentações ao vivo também sofreu grande transformação no mesmo período. "Você não tem mais onde tocar. Os espaços acabaram... A crise que a gente está vivendo nesse país (no mundo!), acabou com muitas oportunidades e espaços para artistas. São poucos espaços, onde dificilmente artistas fora da mídia conseguem chegar" (CELIA VAZ).

Antigamente eu via mais opções de trabalho. Hoje tem muita concorrência e não tem quase lugar, não tem quase espaço para você apresentar o seu trabalho. A profissão de músico se tornou muito valorizada por alguns, uns poucos ganham milhões de dinheiro, e uma outra galera, que toca para caramba, que está ali se esforçando, não ganha nada... está muito desigual. Muito desigual (KÁTIA PRETA).

Do mesmo modo, as musicistas se ressentem da diminuição de séries musicais promovidas por órgãos públicos ou privados. "A gente trabalhava bastante com incentivo da RioArte, do IBAM, da Funarte e outros órgãos de cultura; naquele tempo não existiam os editais culturais. O Rio tinha muitas séries de música de câmara"

Dossiê A Música e suas Determinações Materiais - https://revistaecopos.eco.ufri.br/

ISSN 2175-8689 - v. 23, n. 1, 2020

DOI: 10.29146/eco-pos.v23i1.27436 
(ANDREA ERNEST DIAS); “A gente está com uma escassez séria de música de câmara, o que era para mim uma renda muito boa. As pessoas estão sem esses projetos camerísticos para se segurar. Acho que deu uma baixa não só pra mim, mas para todos" (MARIA TERESA MADEIRA). De modo geral, as narrativas apontam para um grande contraste entre as demandas pelo trabalho em apresentações ao vivo da virada do século XX aos tempos atuais.

Acho que na época em que começou o governo Lula- era uma época em que eu estava em mais atuação - tinha o Projeto Pixinguinha, havia todos os shows de Embaixadas, milhares de shows que eu fiz fora do Brasil, e eu não tenho mais esse tipo de contato atualmente. Na época, tinha os SESCS, tinha uma mobilidade, os festivais que quase não se vê hoje em dia. Até tem, mas é muito menos. E gig também, porque dava para fazer Rio Scenarium, Semente, Carioca da Gema e o Democráticos, em muito mais quantidade. Eu comecei a fazer essas gigs na Lapa em 1998 e fiquei até 2015. Hoje em dia faço bem menos. No quiosque da Lagoa toquei durante 20 anos, e já não tem mais. Várias gigs foram se esfarelando, e não sei se isso tem a ver com o momento, ou com a minha falta de paciência para determinadas coisas... (DANIELA SPIELMANN).

As orquestras, que também não estão numa situação ideal, a gente tem a Sala Cecília Meireles funcionando, mas as séries de música de câmera eu posso te citar umas dez que não existem mais: Música no IBAM, concertos no Banco Francês e Brasileiro nos anos 1980, a Sala Funarte tinha programação direto, a Casa de Cultura Laura Alvin tinha programas de concerto... (MARIA TERESA MADEIRA).

As leis de incentivo fiscal, como a Lei Rouanet, parecem tornar o mercado altamente competitivo e mais acessível a músicos de grande alcance na mídia. "Apresentei três vezes e em todas consegui a aprovação na Lei Rouanet, mas não consegui o patrocínio. Aí, desisti. Fiquei com esse projeto engavetado" (CELIA VAZ).

Olha, eu desenvolvi bastantes trabalhos de produção dos meus próprios trabalhos, dos trabalhos das minhas bandas. Houve momentos em que me dediquei bastante a produção, e quando surgiu a questão da Lei Rouanet, o Ministério da Cultura trouxe essas possibilidades eu fiz muitos projetos, eu escrevi muitos projetos... A gente conseguia aprovar os projetos na Lei Rouanet, mas não conseguia o patrocínio. Isso foi uma coisa que aconteceu não só comigo, mas com muita gente. $\mathrm{Na}$ hora de chegar no patrocinador, não tinha como, era uma barreira intransponível (SUELI FARIA).

Dossiê A Música e suas Determinações Materiais - https://revistaecopos.eco.ufrj.br/

ISSN 2175-8689-v. 23, n. 1, 2020

DOI: 10.29146/eco-pos.v23i1.27436 
Contrastando com os tempos atuais, a grande oferta de espaços para apresentações ao vivo é relacionada a uma grande demanda por este tipo de evento. "A gente lotava, lotava, lotava... Eu fiz Teatro Ipanema várias vezes! Lotava, lotava, lotava..." (CLARA SANDRONI).

Tinha muito público! Fiz muito Mistura Fina, todos os Mistura... tinha esse circuitão. Ainda tinha o Rio Jazz Club, Jazzmania. Quando o trabalho foi amadurecendo, fui ganhando outros lugares. Tinham dois circuitos: o circuito de barzinho - que não tem mais, que era o circuito de música ao vivo (que nem era só música ao vivo, não era só música de fundo, era um showzinho) - e tinha esse outro circuito de público médio. Eram lugares pequenos, como o Mistura. Tinha várias casas com cem lugares, e nessa época a gente fazia quatro shows por mês. Nos anos 1990 ainda existia o Rio Jazz Club. Eu fiz um fixo lá, uma temporada. Bufallo Grill, Gig Saladas... Não conseguiria fazer três shows por semana, nem se eu quisesse, por falta de lugar para fazer (ANDREA DUTRA).

De acordo com alguns depoimentos, as formas de consumo musical parecem ter afetado este mercado.

Eu acho que a música tem se tornado uma coisa mais descartável na vida das pessoas, porque, ao mesmo tempo em que ela está muito mais presente na vida das pessoas, em todos os momentos, se tornou mais descartável. Ao mesmo tempo em que ampliou o acesso à música, banalizou a experiência de ouvir música.... Os momentos das pessoas saírem para ouvir música estão cada vez mais restritos a poucas pessoas que ainda mantêm essa prática. Então, além do mercado ter ficado restrito, em termos de tamanho, além dos cachês, dos direitos da gente estarem cada vez mais diminuídos, sucumbidos, também o público ficou menor... (SUELI FARIA).

A queda na demanda, consequentemente, resultou em menores remunerações.

Havia muitos espaços no eixo Rio-São Paulo durante a década de 1980. Nos anos 90 isso começa a diminuir, mas a música instrumental era ainda muito forte na época. Essa quantidade significativa de festas dentro da comunidade [judaica] ocorreu mais no governo FHC. Quando entrou o governo Lula, as coisas começaram a mudar, e o Celebrare enveredou mais para o segmento de shows do que de festas. Aí a coisa começou a ficar bem diferente. Mudou o modus operandi todo... as festas eram vendidas, embora cada vez mais raras. Nos shows (mais numerosos na nova era), o dinheiro entra via bilheteria, e então os cachês foram ficando cada vez mais baixos. De oitocentos reais foi baixando, baixando, até virar quatrocentos e por aí vai (DEBORAH LEVY).

Dossiê A Música e suas Determinações Materiais - https://revistaecopos.eco.ufri.br/

ISSN 2175-8689 - v. 23, n. 1, 2020

DOI: 10.29146/eco-pos.v23i1.27436 
O couvert, o acerto de divisão dessas casas todas era 80/20. A gente ganhava $80 \%$ e já era uma briga porque a gente queria ganhar $100 \%$. Isso, ao longo do tempo, foi mudando, até que chegamos ao ponto em que estamos hoje: $60 / 40$ - que é o que o Beco das Garrafas propõe, por exemplo. 0 TribOz é 70/30. Isso é considerado muito bom, porque o normal hoje é 60/40 (ANDREA DUTRA).

Em estudos recentes (REQUIÃO, 2017), observamos que o/a trabalhador/a da música, que em outros tempos conseguiu subsistir por meio desta atividade, está se transmutando em Micro Empreendedor Individual (MEI), tal qual o modelo aplicado pelo Serviço Brasileiro de Apoio às Micro e Pequenas Empresas - SEBRAE. "Destacamos que a viabilidade em se 'viver' de música está associada à capacidade em empreender, e que ao lado desse fenômeno vem ocorrendo a chamada 'pejotização', em um processo contínuo de precarização das condições de trabalho e perdas de direitos trabalhistas" (Idem, s.p.). Tal fato é notado por meio das narrativas das musicistas. "Em 2011 eu precisei fazer o MEI por causa do teatro. Foi uma imposição, porque, na verdade, ou você tem o CNPJ para emitir a sua nota fiscal ou você não trabalha, você não é contratado mais" (LILIANE SECCO).

A gente trabalhou de carteira assinada de 2000 a 2002. Entre 2002 e 2006 eu tive que abrir uma empresa. De 2006 a 2014 a gente voltou a ser funcionária de novo. A gente entrou ganhando, na época, uns cinco mil e não sei quanto. Era a maior grana para a época, ano 2000, né? Depois que nos despediram, caiu pela metade. E depois, quando a gente voltou, já era um valor bem mais baixo... (DANIELA SPIELMANN)

\section{Perfil profissional de ontem e de hoje}

Hoje em dia, a pessoa para sobreviver - um músico, primeiro, ele tem que ser um baita músico. Ele tem que ser assessor de imprensa, tem que ser auto-produtor, tem que ser fotógrafo, tem que ser videomaker, tem que mexer muito com Protools e Logic, tem que saber arranjo de orquestra, arranjo de eletrônica, saber funk.

Delia Fischer

Não é tarefa fácil analisarmos a história enquanto ela ocorre. 0 que sabemos é que as transformações no mundo do trabalho vêm acontecendo de forma cada vez mais

Dossiê A Música e suas Determinações Materiais - https://revistaecopos.eco.ufri.br/

ISSN 2175-8689-v. 23, n. 1, 2020

DOI: 10.29146/eco-pos.v23i1.27436 
acelerada. Há muito o que se compreender sobre as novas formas, como elas vêm se dando, a cada momento - a produção, a distribuição e o consumo no campo da música. Também sabemos que as relações e os processos de trabalho se transformam em direção a uma vulnerabilidade cada vez maior de trabalhadoras e trabalhadores, e isso não é exclusividade da música. A precarização do trabalho se mostra sob várias faces: terceirização, intermitência, flexibilidade, empreendedorismo etc. Aos trabalhadores/as do século XXI foi imposta a tarefa de "reinventar-se" (FIRJAN, 2019). "Não existe mais aquele negócio de ficar em casa tocando ou estudando e esperar que vão bater na tua porta para te levar para o show, porque não vão. 0 mercado está esgotado, os espaços cada vez menores, nós estamos numa crise de mercado" (DEBORAH LEVY).

Se eu tivesse 20 anos hoje, acho que teria que ser totalmente diferente do que eu fui. Primeiro porque não existe um mercado de trabalho real, determinado, que você vai ali e vai conseguir o seu trabalho, seu emprego, e ali você vai ficar. Não existe isso mais. Acho que agora a pessoa tem que estar muito mais aparelhada. A concorrência, a competição é muitíssimo maior. Hoje, acredito também que o músico que é muito solitário, tem problemas porque o trabalho depende de uma rede de contatos e artefatos que ele precisa também somar aos dele, para poder estar inserido nesse mundo de hoje, da arte e da cultura (LUNA MESSINA).

Acho que é muito importante a pessoa pensar que o mercado de trabalho, para o músico, vamos dizer, prático, concreto, de você estar ali fazendo a tua música, é uma coisa que me parece cada vez mais restrito. Então você tem que ter possibilidades fora dessa função exatamente, para te complementar. Porque senão entra num processo em que a instabilidade da vida, as dificuldades da vida material, te deixam tão conflituado, que não consegue nem fazer a sua música direito. 0 ser humano tem que ter o mínimo de condições básicas de sobrevivência para poder ter paz de espírito, e, antes de tocar, a gente tem que comer, né? É necessário que a gente garanta essas condições (SUELI FARIA).

O que se impõe agora é: "se você não empreender você não será alguém". Todos temos que ser empresários de nós mesmos? É o famoso discurso da meritocracia, que pode atingir de forma cruel muita gente. Onde estão os empregos de músicos, hoje? Vejo muitos jovens tocando pela questionável "contribuição consciente" do público, tentando descolar um pouco de dinheiro em esquemas de vaquinha. Acho isso bem ruim, desvaloriza o trabalho como eu o entendo (ANDREA ERNEST DIAS).

Françoise Benhamou, ao final do século XX, quando da publicação do seu livro L'économie de la culture, faz um diagnóstico certeiro sobre a direção que ainda trilhamos: "O trabalho dos artistas é descontínuo; as perspectivas de carreira são 
incertas e a gama das remunerações muito ampla" (BENHAMOU, 2007, p.42). Nesse campo de trabalho, cada vez mais os imprevistos e a administração dos riscos são a ordem do dia.

\section{Referências bibliográficas}

BENHAMOU, Françoise. A economia da cultura. São Paulo: Ateliê Editorial, 2007.

BONINO, Sheila. Género y música em Uruguay. In: BONINO, Sheila et al. Apuntes 1.0 - Music@s y Colectivos. Uruguay: Fundación Fans de la Música, p.17-21, 2018.

BRASIL. Lei n.3.857, de 22 de dezembro de 1960. Cria a Ordem dos Músicos do Brasil e Dispõe sobre a Regulamentação do Exercício da Profissão de Músico e dá outras Providências. Disponível em: encurtador.com.br/stGW3. Acesso em: 11 mai. 2019.

BRASIL. Portaria no 3.406 , de 25 de outubro de 1978. Aprova modelos de nota contratual para substituição de Artistas e Técnicos em Espetáculos, de Diversões e para prestação de serviço caracteristicamente eventual por parte desses profissionais. Disponível em: encurtador.com.br/mALOX. Acesso em: 10 jan. 2020.

ESTEVES, Eulícia. Acordes e Acordos: a história do Sindicato dos Músicos do Rio de Janeiro 19071941. Rio de Janeiro: Multiletra, 1996.

MAESTRI, Mário. Revolução e contra-revolução no Brasil [1530-2018]. Porto Alegre: FCM, Coleção Coyocam, 2019

REQUIÃO, Luciana. Trabalho, música e gênero: depoimentos de mulheres musicistas acerca de sua vida laboral. Um retrato do trabalho no Rio de Janeiro dos anos 1980 ao início do século XXI. Rio de Janeiro: Ed. do Autor, 2019. Encontrado em: https://issuu.com/lucianareq/docs/livro_trabalho_musica_genero_fechado. Acesso em: 06 jun. 2020 .

A morte (ou quase morte) do músico como um trabalhador autônomo. In: Colóquio Internacional Marx e o Marxismo 2017: De 0 capital à Revolução de Outubro (1867 - 1917), 2017, Niterói. Anais... Disponível em: encurtador.com.br/bhkr4. Acesso em: 11 mai. 2019.

"Festa acabada, músicos a pé!": um estudo crítico sobre as relações de trabalho de músicos atuantes no estado do Rio de Janeiro. In: Revista do Instituto de Estudos Brasileiros, São Paulo, n. 64, 249-274, ago. 2016.

“Eis aí a Lapa...”: processos e relações de trabalho do músico nas casas de shows da Lapa. São Paulo: Annablume, 2010.

ROSA, Laila; NOGUEIRA, Isabel. O que nos move, o que nos dobra, o que nos instiga: notas sobre epistemologias feministas, processos criativos, educação e possibilidades transgressoras em música. In: Revista Vórtex, Curitiba, v.3, n.2, p.25-56, 2015.

Dossiê A Música e suas Determinações Materiais - https://revistaecopos.eco.ufri.br/

ISSN 2175-8689 - v. 23, n. 1, 2020

DOI: 10.29146/eco-pos.v23i1.27436 
SEGNINI, Liliana. Os músicos e seu trabalho: Diferenças de gênero e raça. In: Tempo Social, v. 26, n. 1, p. 75-86, 1 jun. 2014.

VELON, Marcela. Dama de Espadas: trajetória de um blues carioca. In: Revista Giz. São Paulo, v. 4, n.1, 237-263, Out. 2019.

VICENTE, Eduardo. Música e disco no Brasil: a trajetória da indústria nas décadas de 80 e 90 . São Paulo: USP, 2002. (Tese de doutorado).

ZERBINATTI, Camila Durães, NOGUEIRA, Isabel Porto e PEDRO, Joana Maria. A emergência do campo de música e gênero no Brasil: reflexões iniciais. In: Descentrada, 2 (1), e034, marzo 2018. Encontrada em: http://www.descentrada.fahce.unlp.edu.ar/article/view/DESe034. Acesso em: 06 jan. 2020. 